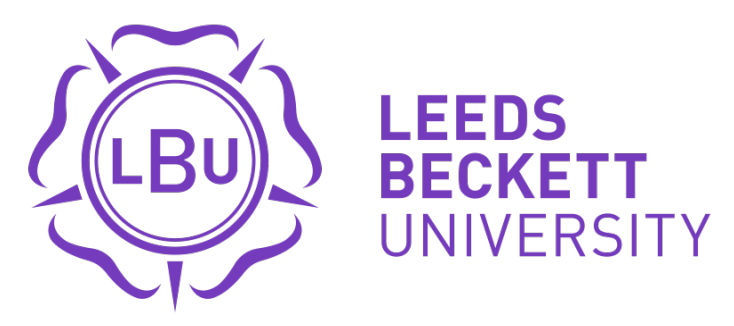

Citation:

Page, D (2017) Conspicuous practice: self-surveillance and commodification in education. International Studies in Sociology of Education, 27 (4). pp. 375-390. ISSN 0962-0214 DOI: https://doi.org/10.1080/09620214.2017.1351309

Link to Leeds Beckett Repository record:

https://eprints.leedsbeckett.ac.uk/id/eprint/3862/

Document Version:

Article (Accepted Version)

This is an Accepted Manuscript of an article published by Taylor \& Francis in International Studies in Sociology of Education on 23 October 2017, available online: http://www.tandfonline.com/10.1080/09620214.2017.1351309

The aim of the Leeds Beckett Repository is to provide open access to our research, as required by funder policies and permitted by publishers and copyright law.

The Leeds Beckett repository holds a wide range of publications, each of which has been checked for copyright and the relevant embargo period has been applied by the Research Services team.

We operate on a standard take-down policy. If you are the author or publisher of an output and you would like it removed from the repository, please contact us and we will investigate on a case-by-case basis.

Each thesis in the repository has been cleared where necessary by the author for third party copyright. If you would like a thesis to be removed from the repository or believe there is an issue with copyright, please contact us on openaccess@leedsbeckett.ac.uk and we will investigate on a case-by-case basis. 


\title{
Conspicuous practice: self-surveillance and commodification in education
}

\author{
Damien Page, Leeds Beckett University
}

Damien.Page@leedsbeckett.ac.uk

This is an Author's Accepted Manuscript of an article to be published in British International Studies in Sociology of Education, copyright Taylor \& Francis. 


\title{
Conspicuous practice: self-surveillance and commodification in education
}

\begin{abstract}
Teachers have always been watched; only more recently have they been surveilled, with senior leaders, peers, students and external stakeholders all collecting performance data. Yet contemporary surveillance in schools and colleges increasingly relies on watching the self, with teachers voluntarily participating in their own surveillance, making their practice visible for easy consumption by interested parties. This article builds on previous work on the surveillance of teachers to argue that this 'conspicuous practice' represents a convergence of surveillance and consumerism, with teachers being recreated as commodities, becoming both the 'merchandise and the marketing agent' in Bauman's (2007) terms, embodying the entrepreneurial self to maximise employability. Through social media promotion such as Twitter and LinkedIn to exploiting open plan learning spaces, teachers engage in conspicuous practice for three main reasons: from fear, to avoid sanction; as a result of acculturation into commodified corporate environments; finally as a means of routine resistance, employing the dramaturgical self for personal gain, to avoid work or to re-appropriate professional practice.
\end{abstract}

\section{Introduction}

Appraisal was just a week away and the teacher sat back in her chair, gazing at the contents of her Personal Development file: the last two teaching observation reports that graded her as 'good with outstanding features'; the spreadsheet of student progress with its pleasing upwards trajectory in her sessions; the online feedback from parents who appreciated her uploading excellent examples of students' work for their parents to view and comment on; the list of CPD courses she had completed; her tutor's feedback on her latest MA essay. She thought about the best order to present them in her appraisal as she logged on to LinkedIn, casually adding her new responsibility for implementing technology in the maths curriculum and checking how many skill-endorsements she had.

In every contemporary educational workplace, teachers are engaged in self-surveillance. While the traditional paradigm of surveillance was founded upon senior leaders intrusively watching teachers, teachers are increasingly watching themselves and reporting what they do. Whether it is by uploading data on student performance or sharing good practice, collating their achievements on LinkedIn or tweeting their latest blog post, teachers willingly and voluntarily make themselves visible. This article builds on previous work on the surveillance of teachers (Page, 2016a and 2017) and begins by analysing self-surveillance in education, moving away from the education literature's preoccupation with panopticism and using a conceptual framework drawn from surveillance studies. In so doing, this conceptual article moves on from prior work to examine the reasons for teachers' participation in selfsurveillance, focusing on the convergence of surveillance and consumerism in education. In developing this argument, it draws on Bauman's concept of seduction into self-surveillance: the desire (indeed, the necessity) to make oneself marketable and employable. From this basis, the article presents its original contribution, the concept of conspicuous practice, work made intentionally visible, and identifies three main antecedents: for some, conspicuous practice is enacted out of fear of sanction, of being categorised as a bad apple and risking their jobs; for others, conspicuous practice is a result of enculturation, of being absorbed into the norms of the neoliberal workplace and reproducing its aims through commodified practice; for others still, conspicuous practice provides a means of routine resistance, using visible work as a means of disguising their actual practices, a means of impression management to gain rewards, re-appropriating control over professional practice or even just avoiding work. It begins with an overview of recent trends of modern surveillance. 


\section{Contemporary surveillance}

While Locke (2010) argues that surveillance has always been a feature of society and its institutions, more recently it has 'emerged as the dominant organizing practice of late modernity' (Lyon, Haggerty and Ball, 2014, ix), proliferating within warfare, the workplace, our streets and our homes. Arising from political and socioeconomic change and instability since the end of the Second World War (Kroener and Neyland, 2014), surveillance is a product of the 'risk society' (Beck, 1992): concerned with preventing the risks it has itself produced, surveillance functions to ameliorate concern for future outcomes, to assuage the anxiety - both social and personal - of future risks. Yet while risk may be the prime antecedent of the growth of surveillance, it is technology that has been the facilitator, making drones ever smaller, monitoring web searches ever more discretely and making personal credit databases ever more sophisticated. While Foucault's (1991) panopticon - the metaphorical rendering of Bentham's penal architecture - has traditionally been central to the theorisation of surveillance, for contemporary surveillance studies panopticism is now 'the ghost lurking within the post-panoptic world' (Lyon, 2006, p10). Instead, contemporary surveillance can be understood within three major trends (Lyon, Haggerty and Ball, 2014). Firstly there is the blurring of boundaries: where once surveillance was primarily a tool of the state (Rule, 2007), now everyone is a surveillance worker (Smith, 2014), co-opted through campaigns to report suspicious activity at one level or to monitor our co-workers' punctuality within open plan offices at another. The second trend is that surveillance has become simultaneously more and less visible: the apparatus of surveillance proliferates in terms of CCTV cameras and personal information databases, watching everything from state interactions such as claiming welfare (Maki, 2011) to online shopping (Lee and Cook, 2014). At the same time, there is an increasing invisibility around the practices of surveillance, an opacity concerning the 'nature and depth of its penetration' (Lyon, Haggerty and Ball, 2014, p3). The final trend is the democratization of surveillance with surveillance focused not just on the powerless but on the powerful, those who have historically resisted scrutiny. Facilitated by the internet and mobile phone technology, the 'synopticon' (Mathiesen, 1997) releases hacked data, it spreads videos of police brutality and pictures of politicians' indiscretions.

Post-panoptic surveillance should be understood as an 'assemblage' (Haggerty and Ericson, 2000), a range of individual technologies that provide an increasingly comprehensive means of collecting data. As such, as unfixed and unrooted, it becomes liquid, 'flexible, mobile, seeping and spreading into many areas of life where once it had only marginal sway' (Bauman and Lyon, 2013). Yet however surveillance 'morphs and mutates' (Lyon, 2010), whatever form it takes or whatever the nature of the assemblage, the primary function of surveillance remains constant: its prime purpose is 'social sorting', the 'classifying drive of contemporary surveillance' (Lyon, 2003). It sorts the terrorist from the patriot, the criminal from the law-abiding citizen, the enemy from the ally. However, surveillance is not only concerned with security binaries, it also sorts the credit-worthy from the uncredit-worthy, the consumer from the economically inactive, the socially mobile from the socially inert. The individual is broken down, abstracted into discrete elements of data before being reassembled through a series of data flows and databases to form a 'decorporealized body, a 'data double' of pure virtuality' (Haggerty and Ericson, 2000) that can be categorised, and ranked leading to differential treatment by the state, banks and online supermarkets. And it is here where contemporary surveillance breaks most distinctly from panopticism: here we find the willing participation of individuals in their own surveillance. 'Haunted by the spectre of exclusion' (Bauman, 2004, p79), terrified at the risk of being placed in an undesireable category, 
individuals are lured into completing online credit checks, entering personal details on surveys and agreeing to cookies on their web browser. Yet this participation is not solely a means of avoiding negative categorization as a citizen and as a consumer. In addition, individuals use social media to position themselves, uploading selfies while on exotic trips or changing their relationship status to 'married', actively seeking to avoid being categorised as poor or lonely. As such, surveillance and consumerism converge as people are 'enticed, nudged or forced to promote an attractive and desireable commodity... and the commodity they are prompted to put on the market, promote and sell are themselves' (Bauman, 2007, p6). Self-surveillance becomes a marketing exercise, a means of avoiding the invisibility that promulgates rejection, negative categorization and suspicion.

\section{The surveillance of teachers}

Just as risk is the driving force of surveillance in general, so it is within schools and colleges, central as they are to the neoliberal risk society (Lake and Carter, 2011), positioned within a marketised and competitive sector. At the macro level there is the risk to the economic prosperity of the country with poorly educated young people unable to advance the UK in global financial standing. At the societal level economic anxiety converges with parental anxiety: parents adopt the role of 'citizen as active entrepreneur of the self' (Davies and Bansel, 2007), exercising neoliberal choice to assuage their anxiety about the future of their children if they achieve poorly at school: unable to get to the best sixth form making them unable to get to the best university making them unable to enter the elite professions making them financially insecure. Then there is the institutional level of risk - embodying performativity and marketization - the risk of a poor inspection, poor exam results or falling league table positions and the risk to child wellbeing. Risk anxiety here is partly moral in terms of failing young people but also individualistic with the senior leaders of badly performing institutions being 'disappeared' (Lepkowska, 2014). And just as the surveillance of teachers shares a common antecedent with wider surveillance, so it shares a primary function - categorisation. While state surveillance may categorise to separate the criminal from the citizen and financial surveillance may categorise to separate the economically secure from the economically inactive, surveillance within education categorises to separate the effective teacher from the ineffective teacher. Rather than social sorting, the surveillance of teachers is professional sorting, weeding out those who pose most risk to inspections, exam results and child welfare. But this is not the panoptic, professional sorting is not achieved via the potential for being watched; sorting is achieved by creating a context of normalized visibility (Page, 2015) with teachers being surveilled constantly and transparently, broken down into abstracted data and reassembled as data doubles, more easily categorised and sorted.

However, before discussing the specifics of the school surveillant assemblage, it must be acknowledged that this conceptualization of the surveillance of teachers can appear overly dystopian and risks overlooking two important elements of the school as a workplace. Firstly, there is the danger that we underplay teacher agency - the fact that schools can be seen as surveillant assemblages does not mean that teachers necessarily become 'dupes'. No matter how seemingly invasive and intrusive surveillance becomes, there is always room for agency and, perhaps more importantly, resistance, even if enacted within the 'cracks and crevices of inter-subjective relations and other quiet subterranean realms of organizational life' (Fleming and Sewell, 2002, p863). Indeed, while commodification is generally seen as stripping the agency and subjectivity from the educational workforce, this article argues that it provides a key means of resistance against the surveillant assemblage. Secondly, surveillance should not always be seen in pejorative terms: without surveillance the effectiveness of teaching and 
leaning would be hard to establish; teacher misbehavior may remain undetected; the accountability risks faced by schools would be impossible to manage.

\section{The surveillant assemblage}

The surveillance of teachers operates at three different levels (Page, 2016a). Firstly there is vertical surveillance. Here there is the traditional means of downwards surveillance in the form of classroom observations and outcomes data analysis but also more recently by means of learning walks, CCTV and organizational designs such as schools-within-schools (Lee and Ready, 2007) that render individual performance more discernable. Yet vertical surveillance is not only top down. Synoptically there is the recording of teachers by students on their mobile phones, uploading videos of teacher misbehavior to YouTube or cyberstalking their teachers' Facebook and Twitter feeds for evidence of unprofessional conduct. Upwards vertical surveillance is also enacted more formally, elicited by senior leaders in the guise of student voice activities, intended to empower young people yet often used as a means of identifying poor educator performance (Page, 2015).

The second level of surveillance is horizontal. In some instances horizontal surveillance is embodied within peer observation of teaching, a collegial means of driving up quality on one hand, on the other hand holding the potential to undermine professional autonomy (Singlehurst, Russell and Greenhalgh, 2008). Then there is the unofficial peer observation outside of the classroom, concertive control (Barker, 1993), the monitoring and norming of group behaviours exercised within open plan offices and open plan learning spaces. Horizontal surveillance also includes parental surveillance as they monitor the effectiveness of their children's teachers (Crozier, 1999) through parental networks (Hassrick and Schneider, 2009), data collected from visits to the institution, open days and shared information among parent groups' online apps such as Homeroom (https://gethomeroom.com) that stream real-time classroom activities.

The third level of surveillance is intrapersonal, self-surveillance. In its traditional form, intrapersonal surveillance is located within reflective practice, omnipresent within teacher training and professional development, enshrined within notions of educator professionalism. Frequently positioned as 'an intrinsically worthwhile activity' (Bleakly, 1999, p320), more critically it may be seen within a 'managerialist orthodoxy' (Clegg, 1999), the co-option of teachers in the surveillant assemblage within education institutions. As such, whether enacted after a teaching session or reflecting during the 'confessional' of the appraisal (Barry et al, 2001) reflective practice offers senior leaders insights into professional work not available by other means: it offers a view on motivations, thoughts, reasoning, analysis, causality, insecurities. Yet more recent forms of intrapersonal surveillance are far less reflective. The contemporary school and college leadership increasingly relies on Management Information Systems to monitor the performance of its students and its teachers. Teachers are required to continually enter data on attendance, behaviour and assessment performance to track progress and predict future outcomes in terms of inspection and exam results. The analysis produced allows senior leaders to identify underperformance within groups of students which allows them to identify the underperformance of individual teachers. Here we see the liquidity of contemporary surveillance, flowing from the intrapersonal to the vertical.

Yet intrapersonal surveillance is not only about evaluative data; it is also founded upon safeguarding concerns. With perceptions of declining trust in professions a theme of modernity (Giddens, 1991) and the media sensationalising stories of serious teacher misbehaviour (Page, 2014a and 2016b), teachers experience a heightened 'risk 
consciousness' (Sachs, 2004), institutionalised paranoia around child abuse. As a result, touching children has become an area where 'fear, confusion, contradictions and moral panic threaten a more measured response' (Piper and Smith, 2003, p879). This risk anxiety - the fear of being accused of sexually-motivated touching - leads teachers to ensure constant physical distance between themselves and children, the intrapersonal policing of proximity. Such is the fear of being labelled an educational 'predator' (Shakeshaft, 2013), teachers avoid touch and avoid closeness. In a further example of surveillant liquidity, this intrapersonal surveillance of distance becomes a need to be seen to be distant, to have senior leaders, peers and even the casual visitor observe that they are not touching children to avoid suspicion (Jones, 2004). Here teachers may exploit the architecture of their school or college, using the glass walls and the open plan learning spaces to be seen not to be touching children as a means of safeguarding themselves.

Intrapersonal surveillance begins as a familiar panoptic construct: in highly performative environments, with the potential for being seen at any time, discipline becomes internalised to produce docile bodies in Foucault's (1991) terms. Yet intrapersonal surveillance is about much more than fear of discipline and punishment and panopticism cannot account for the active, agentive and willing participation of individuals within the practices of surveillance. In part, this participation is driven by risk at the individual level, it is the fear arising from the social sorting of surveillance, of being categorised in one of the undesirable categories: being classified as 'requiring improvement', 'unsatisfactory' or 'coasting'. Sorted into the undesirable categories, employment becomes tenuous, self-worth becomes strained, the meaningfulness of the work of teaching becomes undermined - negative categorisation impacts upon the security of personal finance and personal wellbeing equally. Just as risks to schools and colleges promulgate surveillance at the institutional level, so is this risk replicated at the personal level. However, fear is only part of the story. For Bauman and Lyon (2013), being seen is no longer a menace but a temptation: the 'promise of enhanced visibility, the prospect of 'being in the open' for everybody to see and everybody to notice, chimes well with the most avidly sought proof of social recognition, and therefore of valued 'meaningful' - existence' (p23). From this perspective, rather than being coerced to selfsurveill, teachers are seduced into watching the self, it is the seduction of value and of creating and managing this value, of the recreation of the self into a commodity to be made visible, to be promoted within marketised environments. Here then is the intersection between surveillance and consumerism where teachers become commodities and surveillance becomes advertising. From this point of view, intrapersonal surveillance is not only a strategy of control that is imposed by senior leaders; surveillance and commodification converge and teachers voluntarily engage in watching themselves and making themselves visible.

\section{The commodification of the teacher-self}

In the neoliberal context, the idea that education may be understood in terms of commodification is a familiar one. Performativity has become the means of exercising competition between providers, metrics standing in for traditional notions of quality measurement, acting to 'transform what were social processes of teaching, learning and research into a set of standardised and measurable products' (Ball, 2004). Education becomes a product to be compared against others products, a matter of consumer choice: parents consume qualifications and results for their children, schools are brands to be advertised, promoted and protected, corporatism is expressed in uniforms and marketing. The means of commodification is surveillance, the collection of data to be analysed and abstracted into units of measurement that can be compared and disseminated: surveillance is the process, education as a product is the outcome. From this perspective, schools and colleges have 
'arguably been reconfigured to produce the highly individualized, responsibilized subjects who have become "entrepreneurial actors across all dimensions of their lives"' (Davis and Bansel, 2007). However, this reconfigured duty upon education institutions does not only apply to students - in surveillance-dense environments, teachers similarly are required to take on the mantle of individual entrepreneurialism: they are required to become simultaneously 'promoters of commodities and the commodities they promote... the merchandise and the marketing agents' (Bauman, 2007, p 6). On the one hand - as with surveillance - the commodification of teachers may be understood as coercion, the means of avoiding negative sorting, of being categorised as requiring improvement or inadequate. After all, in the consumer society, the "concept of job security has been replaced by the idea that security lies in being employable' (Aldridge, 2003, p44) and individuals are only employable if they are seen to be employable. On the other hand, commodifying and marketing the self is not only a means of avoiding negative consequences, it is a means of acquisition, of gaining performance related pay, promotion or key projects. Instead of the fear of negative categorisation, the means of commodification is seduction, a central operating concept in the consumerist society, the replacement of needs gratification with the increasing intensity of desire: promotion, performance related pay, greater job satisfaction, greater meaningfulness.

However, as a motivating drive, desire is only effective when it is unsatisfied; only then does the consumer remain active and entrepreneurial, seeking out ever newer potential sources of satisfaction. As Bauman (2007, p47) argues, 'if the search for fulfilment is to go on and if new promises are to be alluring and eye-catching, promises already made must be routinely broken and hopes of fulfilment need to be regularly frustrated'. Although Bauman was here referring to the consumer society in general, frustrated desires could be the motif of education, an endless train of changes ensuring that teachers never find the gratification of certainty or stability. Every new education policy shifts the goalposts, bringing new means to measure teaching quality, new curriculum replacing the established, new ways of reporting student outcomes, new iterations of external accountability frameworks, often being introduced in isolation and engendering ripples of change through the sector. In consumerist terms, this may be understood as the 'Diderot effect' which explains how the introduction of change to a unified environment stimulates dissatisfaction and prompts desire to change everything else in the environment in a perpetual attempt to once again achieve satisfaction. Strangely, the origin of the Diderot effect is a dressing gown.

\section{The Diderot Effect}

In the eighteenth century, Denis Diderot (1713-1784), chief editor and author of the Encyclopedie, wrote an essay entitled 'Regrets in Parting with My Old Dressing Gown'. The essay begins with Diderot bemused as he observes his wonderfully appointed and elegant (yet grim) study, a far cry from its previously chaotic, crowded, humble and happy incarnation. This regretful transformation, he realizes, was the result of a new dressing gown, a gift from a friend. Delighted with the new item initially, he disposed of his 'ragged, humble, comfortable old wrapper'. However, now that he had an immaculate new dressing gown, his desk seemed substandard and he replaced it. With a new dressing gown and desk, the threadbaredness of the tapestry on the wall grated and so he replaced it. Then all the other old, now unsightly items went - books, chairs, engravings and the clock. Such was the impact of the new dressing gown which 'forced everything else to conform with its own elegant tone'. The new dressing gown disrupted the former harmony and accord: while the previous contents of his study were old, scruffy and worn, by being consistently so, there was a unity to the room. The introduction of a new item, especially one so 'imperious', disrupted the unity and caused a ripple effect of dissatisfaction that led to continual replacement. 
Diderot unities (product constellations in marketing terms) are 'highly consistent complements of consumer goods' (McCraken, 1990) related to specific cultural categories. The Diderot effect which arises can be defined as 'a force that encourages the individual to maintain a cultural consistency in his/her complement of consumer goods' (ibid, p123). In a commodified education system, the constellation may be understood in terms of standards and policies, those prescriptive codes and models to which teachers must conform (Page, 2017). School and college teachers for example may desire to be outstanding, as a matter of self-efficacy and maintaining employment and move towards that model as prescribed by external bodies. 'Outstanding' is ostensibly knowable, a prescription of behaviours, attributes and skills that can be acquired and demonstrated. Then a shift happens. The description of an outstanding lesson changes to encompass a new pedagogical practice; the national curriculum replaces seminal texts; industry change affects the vocational curriculum; coursework on a qualification is replaced by a terminal exam. Every change to the educational landscape disrupts the unity of the constellation, the consistency that is built within classrooms and workshops is shattered. The new highlights the old and signals an expectation that all else must be replaced and upgraded to once again attempt to find consistency. The desire to be effective, to achieve excellence, is motivated by frustration as the practice-environment shifts. Frustrated desire then re-engages the entrepreneurial teacher-self to become better, to become fulfilled, to become more employable, to replace all those practices that - compared to the new addition - now look old and outdated. As such, it is the continued frustrated desire inherent in education that promulgates the DIY job of making oneself a 'sellable commodity' (Bauman, 2007).

\section{Conspicuous practice}

If the self is the product that must be marketed, the means of marketing is essential: the self has to become not just visible but visible in the right way and to the right people at the right time. The entrepreneurial self cannot leave it to chance that the most desirable elements of practice are seen, action must be taken - here, then, is teacher agency within the surveillant assemblage. The emphasis within the commodified education environment is therefore on conspicuous practice, analogous to Veblen's (1994) $19^{\text {th }}$ century concept of conspicuous consumption, the visible spending of money to convey messages about social status. Conspicuous practice may be understood similarly: it is the highly public display of practice to convey messages about professional status, an assemblage of individual signifiers forming a Diderot unity that expresses who we are as professional teachers, a constellation marking the individual educator as particularly skilled and differentiated from their competitors.

There are the obvious examples that have long been considered within organizational research: there is presenteeism, especially in open plan offices, and there is the illusion of presenteeism - the archetype of a colleague with two jackets, one to wear and one to leave on the back of his/her chair to simulate presence. There are also those types that exploit the contemporary emphasis on open and/or glass architecture within schools and colleges: the more spectacular teaching sessions may be saved for glass classrooms, the most interactive sessions may be employed during peer observations or captured by video and disseminated amongst the staff and student bodies. Equally - particularly in schools - teachers may more assiduously police their proximity to children within open plan learning spaces where touch may be too easily misconstrued.

However, there are also more subtle forms of surveillant commodification. There are those types which are firmly within the organizational citizenship paradigm and concern the 
sharing of good practice. Long ensconced as the foundation of educational improvement, the sharing of best practice is pure advertising with examples of pedagogical innovation and excellence presented at team meetings, particularly effective resources emailed round to colleagues and managers, new external partnerships pinned to noticeboards. Here, teachers do not wait for their practice to be surveilled during a learning walk or by chance as a senior leader walks past an open plan learning space; instead, they proactively share selected (and the emphasis here is on selected) practice. A related type is the sharing of good news or successes which, while often phrased as a success for the institution, is really a success of the individual: a winner of apprentice of the year from within one's class; a record number of students gaining access to Oxbridge from within a particular tutor's form; the highest percentage of $\mathrm{A}^{*}-\mathrm{C}$ grades ever. These forms of conspicuous practice are essential for the entrepreneurial teacher and operate to develop a brand that, once created, must be maintained.

Of course, individual elements of the teacher brand need to be organized and collated into a coherent conspicuous practice and, thanks to technology, this is easily accomplished through the creation of a digital identity. Preeminent here is LinkedIn, the chief medium of the digital entrepreneurial self, bringing together employment history with its chronology of promotions and breadth of experiences, significant achievements, awards, languages spoken, educational history. And then, true to the notion of liquid surveillance (Bauman and Lyon, 2013), intrapersonal surveillance is conjoined with horizontal surveillance - the watching of peers as colleagues, students and other contacts can endorse you for skills, with individuals collating a points score against 'staff development', 'teaching', 'curriculum design' and many more, the number of endorsements creating a ranking of your abilities, an appendage for one's data double. Once in place, the profile needs continual updating, strengthening the personal brand and, of course, notifying your network of any changes, most notably new jobs and achievements.

While LinkedIn is the most obvious example of the commodification of teachers, the boundaries between social and work media have become blurred, mirroring the adoption of sites such as Facebook and Twitter by corporate interests. Twitter for example now has many vibrant networks of teachers within schools and further education. In some cases Twitter is a valuable source of education news with journalists, practitioners and sometimes policy makers communicating in the same space. However, Twitter is also a source of selfpromotion: an invitation to be a key note speaker at a conference; selfies at said conference at a suitably exotic location; promotions and new roles; awards and other endorsements; meetings with educational celebrities; being blocked by educational celebrities after making a particularly incisive attack against their particular stance. Then there is publicising links to others elements of the digital identify, whether to professional blogs or Facebook profiles or hybrid profile sites such as About.me.

\section{Teachers as fearful, colonised or resisters}

Teachers then, routinely, willingly and agentively participate in their own surveillance, reporting their activities in a variety of forums and for a variety of audiences in routine acts of conspicuous practice. Some teachers participate in their own surveillance to avoid negative categorisation and to avoid sanction: as Enriques argues (in Bauman, 2007, p3): 'those that care for their invisibility are bound to be rejected, pushed aside, or suspected'. This is especially true of educational institutions, driven as they are by the obsession with risk management. The visible are knowable in risk terms, they can be evaluated, measured, categorised, their likelihood of attracting a negative inspection grade or poor completion rates are known and, therefore, manageable. Those who are not visible - or do not make 
themselves visible - are seen as inherently untrustworthy and the greatest risk. An educator who shares no best practice may be assumed to be without best practice; without the enaction of conspicuous practice, teachers may become categorised as risks. From this perspective, the notion of internalising discipline when under the gaze stands true: willing participation within one's own surveillance is out of fear - teachers make themselves visible to avoid sanction.

However, in the post-panoptic setting of modern education, we may also understand intrapersonal surveillance in terms of consumerism and teachers as 'colonised', acculturated into neoliberal organisations where self-surveillance, commodification and conspicuous practice are the norm. Central to this idea is Marx's concept of commodity fetishism, 'the tendency, in a capitalist commodity system, for social relations between people to appear as a relationship between things' (Hudson and Hudson, 2003, p415), obscuring the social relations inherent in production, leading to value residing within commodities rather than the labour that went into its creation. Here we find symmetry with contemporary surveillance studies in the education sector: what is valued is not the social process of teaching, this is obscured; what is valued are the abstract commodities that are produced. The value of teaching is not located within the socialness of pedagogy, the emotional labour imbued within the teacherstudent relationship, the subject expertise or the interpersonal skill. What is fetishized is the grade awarded to a lesson, the attendance percentage, the pass rate and the progression statistics. Teachers from this perspective may be understood as being absorbed within the neoliberal workplace, falling victim to corporate colonization (Casey, 1995), a programme of acculturation which normalises educational fetishism and makes it a condition of employment.

But acculturation does not deny agency, even this does not reduce teachers to powerless dupes - instead, teachers are required to embrace the 'consumerist vocation' (Bauman, 2007), to work on themselves, becoming the best practitioner they can be. This may be accomplished by adopting the profile of 'consumer as explorer' (Gabriel and Lang, 2006), seeking out the most cutting edge CPD bargains, acquiring qualifications, gaining professional statuses, adding post-nominals. Ultimately the aim is to differentiate themselves from their competitors, to have more and better than those also seeking employment, promotion or performance related pay: as Rutherford (1990, p11) suggests, 'it's no longer about keeping up with the Joneses, it's about being different from them'. And from difference comes identity, 'a story that a person writes and rewrites about him or herself, never reaching the end until they die' (Gabriel and Lang, 2006, p83) or, in the context of this article, retire. Yet such a story must be told publically, the practice must be conspicuous, in multiple mediums and through multiple channels, underlining one's unique selling points for personal gain and the achievement of institutional targets. Within such a commodified education context, the acculturated educator participates, making the products of their practice visible as commodities because that is what is required. Not from fear; the commodification of practice is an expectation. From this perspective, self-surveillance is not surveillance at all, it is obscured, disguised as a norm of making practice conspicuous.

Yet there is a third reason for conspicuous practice, one that moves beyond fear or colonization, one that positions participation in self-surveillance and commodification as resistance rather than subordination. But this is not the paradigm of overt resistance, of strikes and organized action; this is the paradigm of 'routine resistance', everyday and often covert acts against the mechanisms of power. From this perspective, the commodification of the self is not from fear or being colonised, it is a conscious means of personal gain: performance related pay, promotion, avoidance of work or the reappropriation of professional autonomy 
amongst other aims. Such strategies may be understood as 'ambiguous accommodation' in Prasad and Prasad's (1998) terms, 'instances of worker cooperation with managerial objectives' (p240) that act to conceal resistance. Here is the realm of the arts of impression management (Goffman, (1974) where the dramaturgical self (Collinson, 2003) seeks to manipulate the way it is perceived (Singh, 2001) in response to 'situations characterized by acute public self-awareness' (Leary and Kowalski, 1990). Take for example the learning walk in schools and colleges where senior leaders literally parade around the corridors and enter any classroom or workshop to observe the session without prior notice. Here, resistance is a matter of dromology, the logic of speed (Virilio, 1986). As the senior leader approaches the classroom to surveill, it is a matter of how quickly the teacher can see the observer coming and how quickly non-desirable practice can be changed. The teacher sitting behind a desk checking emails while their students write a hastily planned essay may, at the sight of the observer walking down the glass corridors, jump up and orchestrate an impromptu role play activity based on the students' writing. Take as another example the carpentry lecturer who follows the prescribed curriculum to the letter, achieving pass rates of $98 \%$ yet inculcates the students into the unofficial rules of the building site that privilege organisational masculinities (see Page, 2014b). From the paradigm of routine resistance, participation in self-surveillance and commodification is far from a matter of subjugation. Such acts do not resist strategies of surveillance that position teachers as commodities; instead, they embrace them, engaging in conspicuous practice not necessarily to become more employable or to gain promotion but for a whole host of individual reasons such as retaining greater control over their teaching or avoiding work. Teachers operate under la perruque, 'the wig' in de Certeau's $(1984$, p24) terms, 'the worker's own work disguised as work for his employer'. Here, conspicuous practice may act as a disguise, an ambiguous accommodation to the commodified workplace that provides space for individualised practice that may be in opposition to official discourses. And the beauty of such routine resistance is that outwardly it appears identical to organisational citizenship, identical to the teacher who has become acculturated into a commodified workplace. What is different is that which cannot be surveilled, the subjectivity of the educator (Ball and Olmedo, 2013).

\section{Conclusion}

Teachers have always been watched but only more recently have they routinely been surveilled with visibility becoming normalised within the contemporary school and college. In a sector of change, where the desire to be competent and fulfilled is continuously frustrated by changes in policy or the codes and models used to define professional status, making oneself marketable, a commodity to be retained and rewarded, becomes a perpetual DIY job. The ever-improving professional then has to ensure they are visible, to advertise their differentiation from their competitors, all seeking the same rewards, promotions, pay rises, key projects. Yet it is remiss to think of teachers only as passive consumers within a commodified sector, engaging in conspicuous practice only out of fear or acculturation. Instead, we should also focus on conspicuous practice as a means of routine resistance, an ambiguous accommodation to the demands of the neoliberal workplace. But we should also resist the reification of conspicuous practice as resistance. In some cases it may operate to regain professional autonomy, to reassert control over the work that is done and how it is done but, as with all workplaces, there will always be those who engage in conspicuous practice for less than professional reasons such as avoiding work and this shouldn't be underestimated. 


\section{References}

Aldridge, A. (2003) Consumption. Cambridge: Polity Press

Ball, S. (2004) Education for sale! The commodification of everything? The Annual Education Lecture, Kings College, London, June 2004.

Ball, S.J. and Olmedo, A., (2013) Care of the self, resistance and subjectivity under neoliberal governmentalities. Critical Studies in Education, 54 (1), 85-96

Barker, J. R. (1993) Tightening the iron cage: concertive control in self-managing teams, Administrative Science Quarterly, 38 (3), 408-437

Barry, J., Chandler, J. and Clark, H. (2001) Between the ivory tower and the academic assembly line, Journal of Management Studies, 38 (1), 87-101

Bauman, Z. (2004) Europe. Cambridge: Polity Press

Bauman, Z. (2007) Consuming life. Cambridge: Polity Press

Bauman, Z. and Lyon, D. (2013) Liquid Surveillance. Cambridge: Polity Press

Beck, U. (1992) Risk society: Towards a new modernity (Vol. 17). New York: Sage

Bleakley, A. (1999) From reflective practice to holistic reflexivity, Studies in Higher Education, 24 (3), 315-330

Casey, C. (1995) Work, Self and Society after Industrialism. London: Routledge

Clegg, S. (1999) Professional education, reflective practice and feminism, International Journal of Inclusive Education 3(2), 167-179

Collinson, D. (2003) Identities and insecurities: selves at work, Organization, 10 (3), 527-547

Crozier, G. (1999) Parental involvement: who wants it? International Studies in Sociology of Education, 9 (3), 219-238

Davies, B. and Bansel, P. (2007) Neoliberalism and education, International Journal of Qualitative Studies in Education, 20 (3), 247-259

De Certeau, M (1984) The Practice of Everyday Life. Berkeley: University of California Press

Fleming, P. and Sewell, G. (2002) 'Looking for the good soldier, Svejk: alternative modalities of resistance in the contemporary workplace', Sociology, 36 (4), 857-873

Foucault, M. (1991) Discipline and punish - the birth of the prison. London: Penguin

Gabriel, Y. and Lang, T. (2006) The unmanageable consumer. London: Sage

Giddens, A. (1991) The consequences of modernity. Cambridge: Polity

Goffman, E (1974) The presentation of Self in Everyday Life. London: Penguin

Haggerty, K and Ericson, R. (2000) The surveillant assemblage, British Journal of Sociology, 51(4), 605-622

Hassrick, E. M., and Schneider, B. (2009) Parent surveillance in schools: A question of social Class, American Journal of Education, 115 (2), 195-225

Hudson, I. and Hudson, M. (2003) Removing the veil? Commodity fetishism, fair trade, and the environment, Organization \& Environment, 16 (4), 413-430

Jones, A. (2004) Risk anxiety, policy, and the spectre of sexual abuse in early childhood Education, Discourse: studies in the cultural politics of education, 25 (3), 321-334

Kroener, I. and Neyland, D. (2014) New technologies, security and surveillance. In K. Ball, K. Haggerty and D. Lyon (Eds) Routledge Handbook of Surveillance Studies. Oxon: Routledge

Lake, R. and Carter, P. (2011) Neoliberalism and education: an introduction, Educational Studies: A Journal of the American Educational Studies Association, 47(2), 107-110

Leary, M.R. and Kowalski, R.M. (1990) Impression management: A literature review and two-component model, Psychological bulletin, 107(1), 34-47

Lee, V. and Ready, D. (2007) Schools Within Schools: Possibilities and Pitfalls of High School Reform. New York: Teachers College Press

Lee, A., and Cook, P. S. (2014) The conditions of exposure and immediacy: Internet 
surveillance and Generation Y, Journal of Sociology, Online First DOI: $1440783314522870.14 / 01 / 15$

Lepowska, D. (2014) A poor Ofsted report could lead to headteachers being 'disappeared',

The Guardian. Available online:

http://www.theguardian.com/education/2014/mar/11/heads-poor-ofsted-reportdismissal-shortages Accessed 6 May 2016

Locke, J. L. (2010) Eavesdropping: An Intimate History. Oxford: Oxford University Press

Lyon, D. (2003) Surveillance as social sorting. In D. Lyon (Ed) Surveillance as Social Sorting: Privacy, Risk and Digital Discrimination. London: Routledge

Lyon, D. (2006) The search for surveillance theories. In D. Lyon (Ed) Theorizing Surveillance. London: Routledge

Lyon, D. (2010) Liquid Surveillance: The Contribution of Zygmunt Bauman to Surveillance Studies, International Political Sociology 4(4), 325-338

Lyon, D., Haggerty, K. and Ball, K. (2014) Introducing surveillance studies. In K. Ball, K. Haggerty and D. Lyon (Eds) Routledge Handbook of Surveillance Studies. Oxon: Routledge

Maki, K. (2011) Neoliberal Deviants and Surveillance: Welfare Recipients under the watchful eye of Ontario Works, Surveillance and Society 9(1/2), 47-63

Mathiesen, T. (1997) The viewer society: Michel Foucault's panopticon revisited, Theoretical Criminology, 1(2), 215-234

McCraken, G. (1990) Culture and Consumption. Bloomington and Indianapolis: Indiana University Press

Page, D. (2014a) Managing serious teacher misbehaviour, School Leadership and Management, 34(3), 269-283

Page, D. (2014b) Desirable organisational masculinities: competition and entrepreneurialism in schools of construction in further education colleges, British Journal of Sociology of Education, 35(6), 895-913

Page, D. (2015) The visibility and invisibility of performance management in schools, British Educational Research Journal, 41(6), 1031-1049

Page, D. (2016a) Conceptualising the surveillance of teachers. British Journal of Sociology of Education (online first) http://www.tandfonline.com/doi/abs/10.1080/01425692.2016.1218752?journalCode= cbse 20

Page, D. (2016b) The multiple impacts of teacher misbehavior, Journal of Education Administration 54 (1), 2-18

Page, D. (2017) The surveillance of teachers and the simulation of teaching. Journal of Education Policy 32 (1): 1-13

Piper, H., and Smith, H. (2003) 'Touch' in educational and child care settings: dilemmas and Responses, British Educational Research Journal, 29(6), 879-894

Prasad A. and Prasad, P. (1998) Everyday struggles at the workplace: the nature and implications of routine resistance in contemporary organizations, Research in the Sociology of Organizations, 15(2), 225-257

Rule, J. (2007) Social control and modern social structure. In S. Hier and J. Greenberg (Eds) The Surveillance Studies Reader. Berkshire: Open University Press

Rutherford, J. (1990) A place called home: identity and the cultural politics of difference, in J. Rutherford (ed.) Identity: Community, Culture, Difference. London: Lawrence and Wishart

Sachs, J. (2004) Watching yourself and others: touch, personal space and risk of harm in the Classroom, paper presented at the AARE Annual Conference, Melbourne, 2004

Shakeshaft, C. (2013) Know the warning signs of educator sexual misconduct, Phi Delta 
Kappan 94(5), 8-13

Singh, V. (2001) Impression management, commitment and gender: managing others' good Opinions, European Management Journal, 19(2), 183-194

Singlehurst, D., Russell, J., and Greenhalgh, T. (2008) Peer observation of teaching in the online environment: an action research approach, Journal of Computer Assisted Learning, 24(5), 383-393

Smith, G.J.D. (2014) Surveillance work(ers). In K. Ball, K. Haggerty and D. Lyon (Eds) Routledge Handbook of Surveillance Studies. Oxon: Routledge

Veblen, T. (1994) The Theory of the Leisure Class. New York: Dover

Virilio, P. (1986) Speed and politics. New York: Semiotext 